\title{
GENOTOXIC POTENTIAL OF SOILS IRRIGATED WITH TREATED WASTEWATER: CASE OF THE CEBALA-BORJ TOUIL IRRIGATED PERIMETER (TUNISIA)
}

\author{
SOUGUIR, D..$^{*}$ - HÖRMANN, G. ${ }^{2}-$ HALIS, S. ${ }^{3}-$ JATOI, B. W. ${ }^{4}-$ HACHICHA, M. ${ }^{1}$ \\ ${ }^{I}$ Institut National de Recherches en Génie Rural, Eaux et Forêts, Université de Carthage, \\ Ariana, Tunisia \\ ${ }^{2}$ Department of Hydrology and Water Resources Management, Kiel University, Kiel, Germany \\ ${ }^{3}$ Department of Agricultural and Biosystems Engineering, North Dakota State University, \\ Fargo, ND, USA \\ ${ }^{4}$ Chemistry Institute, Shah Abdul Latif University, Khaipur, Pakistan \\ *Corresponding author \\ e-mail:souguir.dalila@yahoo.com \\ (Received $28^{\text {th }}$ Aug 2020; accepted $19^{\text {th }}$ Nov 2020)
}

\begin{abstract}
In order to assess the effects of treated wastewater (TWW) irrigation on soil, a study was conducted in the TWW irrigated perimeter Cebala-Borj Touil, using the Vicia-micronucleus test and soil leachates. The study was carried out in 4 sub-perimeters $\left(\mathrm{C}_{3}{ }^{+}, \mathrm{C}_{10^{+}}, \mathrm{C}_{3}{ }^{-}\right.$and $\left.\mathrm{C}_{10}{ }^{-}\right)$with different secondary effluent irrigations histories. The salinity of the soil leachates developed in two directions: (i) salinity decreased with increasing duration of TWW irrigation for $\mathrm{C}_{3}{ }^{+}$and $\mathrm{C}_{10}{ }^{+}$; (ii) salinity increased with the longer time since the last TWW irrigation for $\mathrm{C}_{3}{ }^{-}$and $\mathrm{C}_{10}{ }^{-}$. The heavy metal contents differed between the studied leachates. Growth parameters and membrane integrity did not show significant differences between the plants exposed to the leachates and controls $\left(\mathrm{C}_{0}\right)$. However, the root tips treated with the leachates showed changes in mitotic activity, induction of micronuclei and appearances of chromosomal and nuclear abnormalities. The genotoxicity may be attributed to (i) individual effects of contaminants, and/or (ii) synergetic or antagonist interactions of different contaminants contained in the leachates. The micronucleus test seems to be a possible early warning system that allows the detection of soil genotoxicity, whereas growth parameters and membrane integrity did not show any variation during the 2-day exposure period.
\end{abstract}

Keywords: abnormalities, heavy metals, micronucleus test, non-conventional water, salinity

\section{Introduction}

Agriculture in arid and semi-arid Mediterranean regions relies mainly on irrigation. Since the water resources in these regions are scarce, the use of non-conventional water like wastewater effluent for an irrigation purpose is increasing more and more. Tunisia is a typical example for Mediterranean region with about 12 million inhabitants, a semiarid climate and only 4.8 billion $\mathrm{m}^{3}$ of renewable water resources (less than $450 \mathrm{~m}^{3} /$ inhabitant/year). An additional constraint in the country is salinity. About $10 \%$ of the soils and $50 \%$ of the water resources are impacted from the salinity with the concentration of $1.5 \mathrm{~g} / \mathrm{l}$ or more (Hachicha, 2007).

Thus, to fight water scarcity, Tunisia has adopted a strategy to preserve its water sources, which includes the use of alternative water sources and the increased control of water demand in all socioeconomic sectors. Tunisia has a long experience in using socalled "non-conventional" water resources such as treated wastewater (TWW). Standards for the Tunisian wastewater treatment plant effluent discharge (TN 106.02 
revised) (JORT, 2018) and reuse in agriculture (TN 106.03, under revision) (INNORPI, 1989) have been established. In these standards, salt, heavy metal, and pathogen limits in the wastewater effluent were determined. In addition, a list of the plants that can be irrigated using wastewater effluent was set.

Reuse of effluents in agriculture can be a reliable alternative to cope with the irrigation water scarcity for farmers. However, long-term irrigation with nonconventional water may result in long-term gradual changes of soil physical properties and an accumulation of contaminants like salts and heavy metals. For the risk assessment of contaminated soils, guidelines based on physicochemical analyses were developed. However, this approach only covers the direct toxic effects of contaminants on living organisms, but not the complex synergetic or antagonistic effects. Therefore, simple physical and chemical analyses do not provide enough information about the complex effects of pollutants on organisms. Thus, biological tests using higher plants are necessary to test toxicity, the genotoxicity and the genome disruption. The use of plant bioassays for testing and monitoring soil and water pollution has many advantages: these organisms are easy to handle, do not require maintenance, have a wide applicability and are inexpensive (Grant, 1993).

The micronucleus assay using Vicia faba is a common genotoxicity test for environmental contaminants. It provides detailed information about abnormal cell division, micronucleus formation and chromosomal and nuclear damages. Chromosomal aberrations include chromosome structural aberrations (clastogenesis) and spindle malfunction affecting the chromosome number (aneugenesis). This bioassay has been used to assess the genotoxicity of contaminated soil, sediment, organic material, water, and industrial effluent (Smaka-Kincl et al., 1996; Sta et al., 2012; Renjana et al., 2013; Cotelle et al., 2015; Corrêa et al., 2016). It was used for several stress conditions such as heavy metals (Souguir et al., 2008, 2011; Yi et al., 2010), olive mill wastewater (El Hajjouji et al., 2007), pesticide (Sta et al., 2012) and diesel exhaust particules (Corrêa et al., 2016).

This study is part of a research program evaluating the impact of non-conventional water application on soil properties, which resulted in many research papers of Tunisian scientists. The most important subjects were the development of soil salinity, and the distribution of heavy metals after irrigation with both saline water and TWW, e.g. in Sfax, Zaouit Sousse, etc. (Klay et al., 2010; Kallel et al., 2012; Belaid et al., 2012; Ferjani et al., 2013). Other studies focused on xenobiotic organics, polycyclic aromatic hydrocarbons, polychlorinated biphenyles and organochlorinated pesticides in soils near Nabeul (Mahjoub et al., 2009; Haddaoui et al., 2016). However, as of our knowledge, this is a first study that use bioassays to assess the soil state after irrigation with wastewater effluent. The aim of our work was the use of the Vicia-micronucleus test to assess genotoxic effects of short and long-term irrigations with secondary effluents on the soil of Cebala-Borj Touil, the oldest and biggest irrigated perimeter in Tunisia.

\section{Materials and methods}

\section{Study area}

The study was carried out in the Cebala-Borj Touil area (Fig. 1), the largest irrigation area in Tunisia, with 3,200 ha of total 8,100 ha irrigated area (about 40\%) with treatment plant effluent. It is located $8 \mathrm{~km}$ north of Tunis with an average rainfall of $450 \mathrm{~mm} / \mathrm{year}$; the rainy season extends from October to March. The groundwater is 
very shallow and unsuitable for irrigation due to high salinity levels. The effluents were supplied by the outflow of three wastewater treatment plants (WWTPs) of Great Tunis (Choutrana, Cherguia and Cotière Nord). These plants treat almost $75 \%$ of the total urban, domestic and industrial discharges of the City of Tunis. The WWTPs are equipped with primary and secondary treatment units to remove organic pollution.

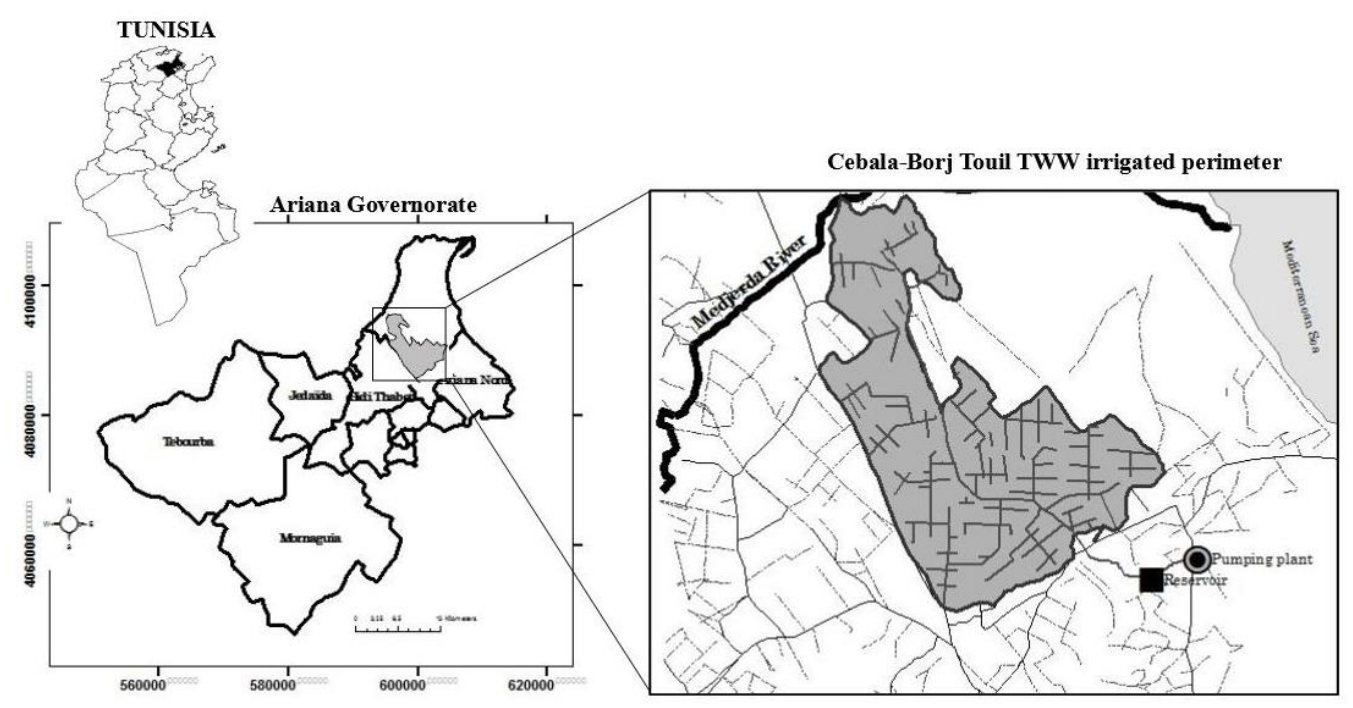

Figure 1. Location of the Cebala-Borj Touil TWW irrigated perimeter

Effluents from these plants are discharged to the Mediterranean Sea through the ONAS and Khelij canals. The wastewater effluent is pumped $4 \mathrm{~km}$ downstream of Choutrana to a buffer reservoir located 120 meters higher than the irrigated farms. Each year, only a small part of the water is used to irrigate the Cebala area, the rest flows directly to the sea. Irrigation with treated wastewater started in 1989. The method used is gravity irrigation, which causes a prolonged stagnation of water in the depressions, especially in the areas with high groundwater level. The fields are used for winter farming to grow cereals (wheat, barley, and hay) and fodder crops (berseem, green barley, and vetch-hay).

\section{The characterization of treatment plant effluent}

Table 1 lists annual averages of 2010, 2015, and 2017 of pH, salinity and chemical elements of the TWW used for irrigation and the Tunisian standard thresholds for the reuse of secondary effluents in irrigation (NT106.03). In 2017, the TWW was characterized by a basic $\mathrm{pH}$ (7.91) and an average salinity, measured by the electrical conductivity (EC) of about $5.03 \mathrm{dS} / \mathrm{m}$ with high contents of sodium and chloride. The content of trace elements does not exceed the values of the Tunisian standard, except for Cr. A comparison of the different years shows an increase in salinity and metal concentrations.

\section{Soil sampling and extraction}

The Cebala-Borj Touil perimeter is composed of many sub-perimeters with siltyclayey soils. The fine particles (clay + silt) exceed $80 \%$ and sand is about $17 \%$. The 
content of organic matter is very low (about $0.7 \%$ ) compared to high content of total carbonate of $41 \%$, determined by ISO 10693 .

Table 1. Characteristics of the TWW used for irrigation in the Cebala-Borj Touil irrigation perimeter

\begin{tabular}{c|c|c|c|c}
\hline \multirow{2}{*}{ Parameter } & \multicolumn{3}{|c|}{ Average } & Standard $^{\mathbf{c}}$ \\
\cline { 2 - 5 } & $\mathbf{2 0 1 0}^{\mathbf{a}}$ & $\mathbf{2 0 1 5}^{\mathbf{b}}$ & $\mathbf{2 0 1 7}$ & NT106.03 \\
\hline $\mathrm{pH}$ & 8.2 & 7.82 & 7.91 & $6.5-8.5$ \\
$\mathrm{EC}(\mathrm{dS} / \mathrm{m})$ & 3.70 & 4.02 & 5.30 & 7.0 \\
$\mathrm{Cl}^{-}(\mathrm{me} / \mathrm{l})$ & - & 20.84 & 39.95 & 56.6 \\
$\mathrm{SO}_{4}{ }^{2-}(\mathrm{me} / \mathrm{l})$ & - & 8.86 & 8.72 & - \\
$\mathrm{HCO}_{3}{ }^{-}(\mathrm{me} / \mathrm{l})$ & - & 10.11 & 8 & - \\
$\mathrm{Na}^{+}(\mathrm{me} / \mathrm{l})$ & - & 21.78 & 28.61 & - \\
$\mathrm{Ca}^{2+}(\mathrm{me} / \mathrm{l})$ & - & 3.17 & 12.16 & - \\
$\mathrm{Mg}^{2+}(\mathrm{me} / \mathrm{l})$ & - & 5.33 & 9.33 & - \\
$\mathrm{K}^{+}(\mathrm{me} / \mathrm{l})$ & - & 0.92 & 1.07 & - \\
$\mathrm{Cd}(\mathrm{mg} / \mathrm{l})$ & 0.002 & 0.010 & 0.002 & 0.01 \\
$\mathrm{Co}(\mathrm{mg} / \mathrm{l})$ & 0.008 & 0.020 & 0.011 & 0.1 \\
$\mathrm{Cr}(\mathrm{mg} / \mathrm{l})$ & 0.003 & 0.020 & 0.117 & 0.1 \\
$\mathrm{Cu}(\mathrm{mg} / \mathrm{l})$ & 0.008 & 0.020 & 0.010 & 0.5 \\
$\mathrm{Fe}(\mathrm{mg} / \mathrm{l})$ & 0.048 & 0.210 & 0.078 & 5.0 \\
$\mathrm{Mn}(\mathrm{mg} / \mathrm{l})$ & 0.006 & 0.080 & 0.036 & 0.5 \\
$\mathrm{Ni}(\mathrm{mg} / \mathrm{l})$ & 0.022 & 0.030 & 0.038 & 0.2 \\
$\mathrm{~Pb}(\mathrm{mg} / \mathrm{l})$ & 0.08 & 0.030 & 0.037 & 1.0 \\
$\mathrm{Zn}(\mathrm{mg} / \mathrm{l})$ & 0.032 & 0.030 & 0.009 & 5.0 \\
\hline
\end{tabular}

${ }^{a}$ Technical report (2010-2014)

${ }^{\mathrm{b}}$ Dahmouni et al. (2019)

'Tunisian standard for TWW reuse in irrigation (NT106.03)

For this study, 4 sub-perimeters were chosen. The parcels have different TWW irrigation histories: The $\mathrm{C}_{3}{ }^{+}$and $\mathrm{C}_{10}{ }^{+}$parcels have been irrigated with TWW for 3 and 10 years, respectively. The $\mathrm{C}_{3}{ }^{-}$and $\mathrm{C}_{10}{ }^{-}$parcels were initially meant to be irrigated with TWW for 12 years, but the supply has stopped 3 and 10 years ago, respectively. Irrigation was stopped for several reasons: the guidelines prohibited cultivation of vegetables and cash crops in TWW irrigated areas and young people were not interested any more to work in the agricultural sector. For a correct assessment of the soil TWW effect, a non-irrigated field $\mathrm{C}_{0}$, with silty-clayey soils and without any irrigation with secondary effluents, was selected near the studied fields. It was used to determine the background values for $\mathrm{pH}$, electric conductivity (EC), heavy metals, and genotoxicity. Soil samples were taken in February 2017 after a rainy period $(14 \mathrm{~mm})$ from $0-40 \mathrm{~cm}$ using a Dutch auger. A composite sample was obtained from three sub-samples collected from each plot. The $6 \mathrm{~kg}$ mixed soil sample was air-dried and sieved at $2 \mathrm{~mm}$. The leachate was produced with deionized water with a liquid-to-soil ratio of 1:1. After shaking with $120 \mathrm{rpm}$ for $8 \mathrm{~h}$, the soil solution was centrifuged with 3,500 rpm for $10 \mathrm{~min}$ and then the supernatant was filtered. The leachate was immediately used for the physicochemical analysis and the plant treatments. 


\section{Leachate analysis}

$\mathrm{pH}$ and electric conductivity (EC) have been respectively measured with a $\mathrm{pH}$-meter Lutron pH 211-type and a conductimeter Cond./TDS, AZ 8361-type. Chloride was measured with the silver-nitrate method and sulfate with the nephelometric method using barium chloride. Bicarbonate was determined after titration with sulfuric acid. Sodium and potassium were analyzed by flame emission spectroscopy (Jenway, PFP7) and calcium and magnesium were determined with the EDTA-complexometric titration method. Heavy metals in the leachate were analyzed by atomic absorption spectrometry (Perkin Elmer).

\section{V. faba treatments}

$V$. faba seeds (Tunisian Chahbi variety) were surface sterilized with $10 \%$ sodium hypochlorite, rinsed several times with water and placed on moistened filter paper at $25^{\circ} \mathrm{C}$ for 3 - 4 days. Subsequently, the roots were exposed to the 5 soil leachates with three replicates. After $48 \mathrm{~h}$ of exposure, the seedlings were rinsed a few times with distilled water and divided into three groups: the first was used for growth measurement; the second to determine membrane integrity and the third for the micronucleus test.

\section{Growth parameters}

Control and treated seedlings were separated into roots and hypocotyls for the measurement of root length, fresh and dry matters. Root length was determined by measuring the length of the whole root after the leachate treatments. For each treatment, the length of, at least, 10 roots were measured. Dry matter was determined after drying the fresh parts of 27 plants in an oven at $65^{\circ} \mathrm{C}$ for 2 to 3 days until constancy weight.

\section{Assessment of the loss of integrity of the plasma membrane}

The loss of the plasma membrane integrity was evaluated with three root tips by a spectrophotometric test with Evans blue as described by Souguir et al. (2011). The first centimeter of the roots was incubated in $0.025 \%$ Evans Blue $(\mathrm{m} / \mathrm{v})$ for $30 \mathrm{~min}$, rinsed for $15 \mathrm{~min}$ and squashed in a $800 \mu \mathrm{l}$ solution of $50 \% \mathrm{MeOH}(\mathrm{v} / \mathrm{v})$ and $1 \%$ sodium dodecyl sulphate (SDS). The root extracts were then incubated for $15 \mathrm{~min}$ at $50{ }^{\circ} \mathrm{C}$. The homogenate was centrifuged at $14,000 \mathrm{rpm}$ for $15 \mathrm{~min}$. The optical density of the supernatant was determined spectrophotometrically at $600 \mathrm{~nm} .9$ roots were used to assess the plasma membrane integrity under each treatment.

\section{Genotoxicity assessment}

The genotoxicity of the leachate was tested with the micronuclei of the meristematic roots of $V$. faba. The root tips were cut, placed overnight in Carnoy's fixation solution containing ethanol and glacial acetic acid (3:1), and stored in the dark in $70 \%$ of ethanol before being hydrolyzed with $1 \mathrm{~N} \mathrm{HCl}$ as described by Souguir et al. (2008). For each treatment, at least 12 roots were used. The root meristematic tissues were stained with orcein, squashed between a slide and a coverslip, and finally examined under a research microscope (Leica DM2500) with 40 or 100 times magnification.

Three slides were prepared for each of the three replicates and a total of 9,000 cells were observed from nine separate slides per treatment. Mitotic cells were expressed as 
the number of dividing cells in 1,000 observed cells. Micronuclei were observed in both interphasic and mitotic cells. Only micronuclei observed in interphases were counted and expressed in terms of micronuclei per 1,000 interphase cells.

The cells were also scored for micronuclei in dividing cells, clastogenic (bridge, fragment and stickiness,) and aneugenic (non-disjointed and isolated chromosomes) abnormalities. The number of each abnormality was expressed per 100 cells. The preparations were photographed with a digital camera (Canon EOS 1100) attached to the microscope.

\section{Statistical analysis}

The results are presented as the means \pm standard deviation (SD) obtained from three replicates. All the treatments were compared to the leachate of the site $\mathrm{C}_{0}$. Significant differences were determined by Tukey's test at the $0.05 \%$ confidence level with the SPSS software (IBM SPSS statistics, v20).

\section{Results}

\section{Leachate characterization}

$\mathrm{pH}$, salinity, and ionic composition of the leachates are shown in Table 2. The $\mathrm{pH}$ was basic from 7.75 to 8.19 with no difference between irrigated and non-irrigated soils (8.04). The salinity of soils irrigated with secondary effluents was higher compared to the $0.69 \mathrm{dS} / \mathrm{m}$ of the control soil $\left(\mathrm{C}_{0}\right)$. Two trends are visible: (i) On soils with continuous irrigation, the salinity decreased with increasing irrigation duration. The soil with 3 years of continuous TWW irrigation showed an $\mathrm{EC}_{1: 1}(2.03 \mathrm{dS} / \mathrm{m})$ higher than soils receiving TWW for 10 years $(1.07 \mathrm{dS} / \mathrm{m})$; (ii) Salinity increased in periods without a TWW irrigation from about $3.5 \mathrm{dS} / \mathrm{m}$ on $\mathrm{C}_{3}{ }^{-}$to $5.03 \mathrm{dS} / \mathrm{m}$ after 10 years on $\mathrm{C}_{10}$.

Table 2. $p H$, salinity and ionic composition of leachates

\begin{tabular}{c|c|c|c|c|c}
\hline Parameters & $\mathbf{C o}_{\mathbf{0}}$ & $\mathbf{C}^{+}$ & $\mathbf{C}_{10^{+}}$ & $\mathbf{C}^{-}$ & $\mathbf{C}^{-}{ }^{-}$ \\
\hline $\mathrm{pH}$ & $8.04 \pm 0.02 \mathrm{a}$ & $8.0 \pm 0.00 \mathrm{a}$ & $8.19 \pm 0.00 \mathrm{a}$ & $8.03 \pm 0.01 \mathrm{~b}$ & $7.75 \pm 0.03 \mathrm{a}$ \\
$\mathrm{EC}(\mathrm{dS} / \mathrm{m})$ & $0.69 \pm 0.02 \mathrm{a}$ & $2.03 \pm 0.00 \mathrm{c}$ & $1.07 \pm 0.00 \mathrm{c}$ & $3.50 \pm 0.01 \mathrm{~b}$ & $5.03 \pm 0.02 \mathrm{~d}$ \\
\hline Ionic composition & & & & & \\
\hline $\mathrm{Cl}^{-}(\mathrm{me} / \mathrm{l})$ & $3.29 \pm 1.62 \mathrm{a}$ & $8.46 \pm 0.00 \mathrm{~b}$ & $1.88 \pm 0.81 \mathrm{~b}$ & $9.40 \pm 0.81 \mathrm{a}$ & $36.19 \pm 4.07 \mathrm{c}$ \\
$\mathrm{HCO}_{3}^{-}(\mathrm{me} / \mathrm{l})$ & $4.66 \pm 0.28 \mathrm{~b}$ & $8.00 \pm 1.32 \mathrm{ab}$ & $5.83 \pm 0.28 \mathrm{bc}$ & $5.50 \pm 0.50 \mathrm{c}$ & $3.00 \pm 0.50 \mathrm{a}$ \\
$\mathrm{SO}_{4}^{2-}(\mathrm{me} / \mathrm{l})$ & $7.46 \pm 0.62 \mathrm{ab}$ & $8.64 \pm 1.85 \mathrm{~b}$ & $5.50 \pm 2.22 \mathrm{~b}$ & $9.82 \pm 0.56 \mathrm{a}$ & $25.98 \pm 0.52 \mathrm{c}$ \\
$\mathrm{Na}^{+}(\mathrm{me} / \mathrm{l})$ & $3.75 \pm 0.22 \mathrm{a}$ & $11.90 \pm 3.90 \mathrm{~b}$ & $5.55 \pm 0.34 \mathrm{ab}$ & $8.71 \pm 0.09 \mathrm{ab}$ & $36.30 \pm 5.28 \mathrm{c}$ \\
$\mathrm{Ca}^{2+}(\mathrm{me} / \mathrm{l})$ & $2.66 \pm 0.28 \mathrm{a}$ & $4.33 \pm 2.02 \mathrm{a}$ & $2.33 \pm 0.28 \mathrm{a}$ & $3.00 \pm 0.50 \mathrm{a}$ & $10.66 \pm 2.75 \mathrm{~b}$ \\
$\mathrm{Mg}^{2+}(\mathrm{me} / \mathrm{l})$ & $3.66 \pm 1.25 \mathrm{ab}$ & $2.83 \pm 1.52 \mathrm{ab}$ & $1.83 \pm 0.76 \mathrm{~b}$ & $5.66 \pm 0.28 \mathrm{a}$ & $10.33 \pm 2.02 \mathrm{c}$ \\
$\mathrm{K}^{+}(\mathrm{me} / \mathrm{l})$ & $0.02 \pm 0.00 \mathrm{a}$ & $0.35 \pm 0.06 \mathrm{~d}$ & $0.05 \pm 0.00 \mathrm{~d}$ & $0.14 \pm 0.00 \mathrm{~b}$ & $0.07 \pm 0.01 \mathrm{c}$ \\
\hline
\end{tabular}

$\mathrm{C}_{0}$ : never irrigated; $\mathrm{C}_{3}{ }^{+}$: irrigated for 3 years; $\mathrm{C}_{10}{ }^{+}$: irrigated for 10 years; $\mathrm{C}_{3}{ }^{-}$not irrigated for 3 years and $\mathrm{C}_{10}$ : not irrigated for 10 years. Values are mean $\pm \mathrm{SD}$. Different letters indicate significant differences at $P<0.05$ according to Tukey's test

The leachates were also analyzed for trace elements (Fig. 2). For the soil $\mathrm{C}_{0}$, the $\mathrm{Co}$ and $\mathrm{Cd}$ contents were lowest, the concentrations of $\mathrm{Cu}$ ranged from 0.005 to $0.009 \mathrm{mg} / \mathrm{l}$, for $\mathrm{Ni}$ and $\mathrm{Pb}$ from 0.000 to $0.007 \mathrm{mg} / \mathrm{l}$, and for $\mathrm{Cr}$ from 0.001 to $0.014 \mathrm{mg} / \mathrm{l}$. The $\mathrm{Mn}$ 
and $\mathrm{Fe}$ contents were highest in $\mathrm{C}_{0}$ reaching $0.018 \mathrm{mg} / \mathrm{l} \mathrm{Mn}$ and $0.5 \mathrm{mg} / \mathrm{l} \mathrm{Fe}$. Heavy metal contents in irrigated soils were higher than in $\mathrm{C}_{0}$. The highest ranges of $\mathrm{Cd}$, $(0.010-0.017 \mathrm{mg} / \mathrm{l})$ and $\mathrm{Fe}(0.762-0.872 \mathrm{mg} / \mathrm{l})$ were observed in $\mathrm{C}_{10}{ }^{+}$while the highest concentrations of $\mathrm{Cu}, \mathrm{Co}, \mathrm{Pb}, \mathrm{Ni}$ and $\mathrm{Cr}$ were detected in $\mathrm{C}_{10^{-}}$. In this soil leachate $\left(\mathrm{C}_{10^{-}}\right)$, the heavy metal contents varied between 0.010 and $0.017 \mathrm{mg} / \mathrm{l}$ for $\mathrm{Cu}$, between 0.005 and $0.013 \mathrm{mg} / \mathrm{l}$ for $\mathrm{Co}$, between 0.021 and $0.044 \mathrm{mg} / \mathrm{l}$ for $\mathrm{Pb}$ and $\mathrm{Ni}$, and between 0.124 and $0.161 \mathrm{mg} / \mathrm{l}$ for $\mathrm{Cr}$.
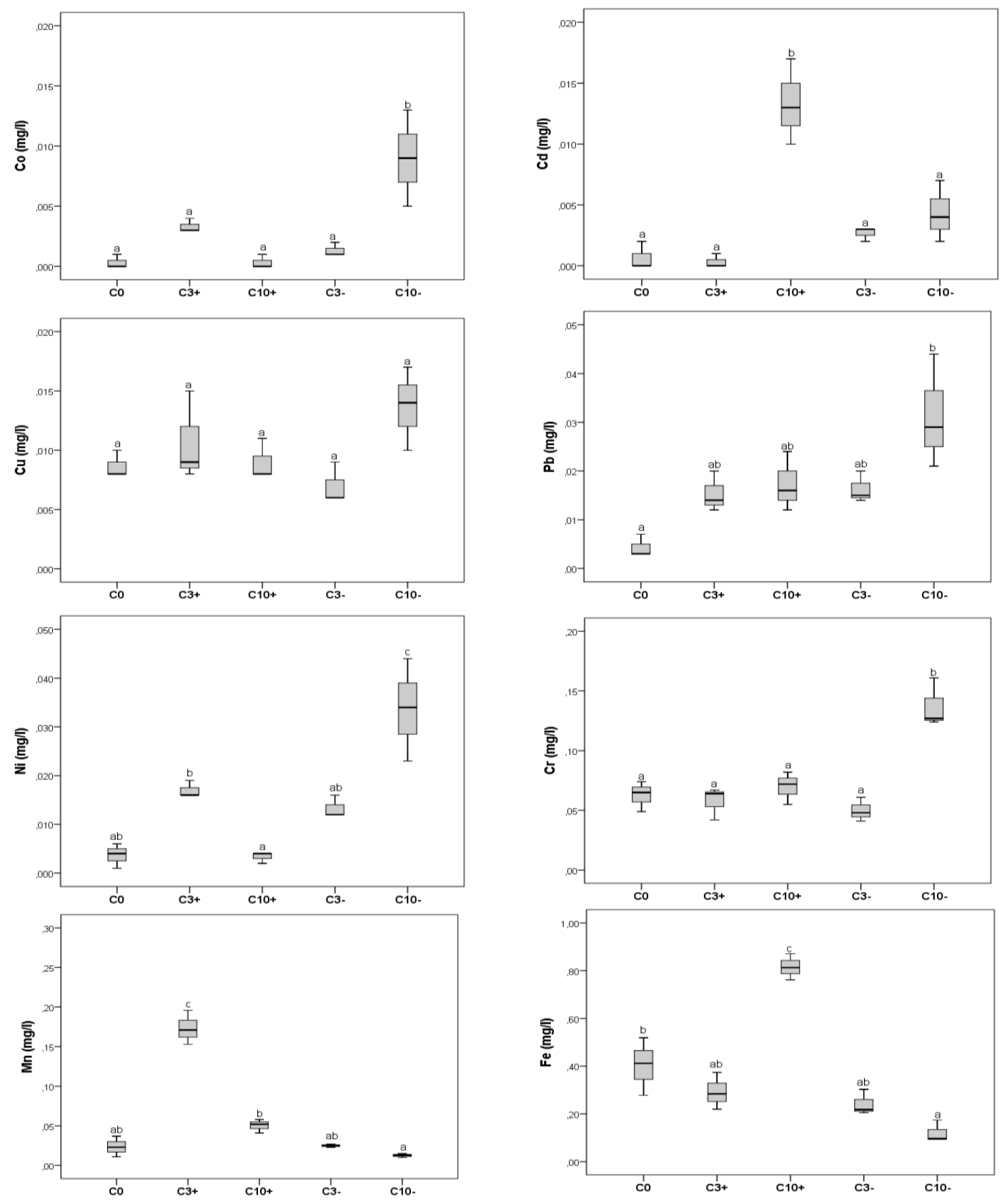

Figure 2. Boxplots for the heavy metal compositions in soil leachates. The horizontal lines within the boxes represent the median values. $C_{0}$ : soil never irrigated with the TWW; $\mathrm{C}_{3}{ }^{+}$and $C_{10}{ }^{+}$: soils irrigated for 3 and 10 years, respectively; $C_{3}{ }^{-}$and $C_{10}{ }^{-}$: soils not irrigated for 3 and 10 years, respectively. Different letters indicate significant differences at $P<0.05$ according to

Tukey's test 


\section{Growth parameters and membrane integrity}

The $V$. faba growth parameters were recorded after $48 \mathrm{~h}$ of exposure to the leachates. The root length measurements did not show significant differences between control and treated plants (Table 3). Likewise, fresh and dry matter and the area of the roots were not different from the control.

Table 3. Growth parameters of the V. faba seeds exposed to different leachates

\begin{tabular}{c|c|c|c|c|c}
\hline Parameters & $\mathbf{C}_{\mathbf{0}}$ & $\mathbf{C}_{3^{+}}$ & $\mathbf{C}_{\mathbf{1 0}}{ }^{+}$ & $\mathbf{C}_{3^{-}}$ & $\mathbf{C}_{\mathbf{1 0}^{-}}$ \\
\hline $\begin{array}{c}\text { Root length }(\mathrm{cm}) \\
\text { Fresh matter }(\mathrm{g})\end{array}$ & $3.10 \pm 0.60 \mathrm{a}$ & $2.80 \pm 0.50 \mathrm{a}$ & $3.07 \pm 0.29 \mathrm{a}$ & $2.70 \pm 0.50 \mathrm{a}$ & $3.60 \pm 0.50 \mathrm{a}$ \\
\hline Root & $0.41 \pm 0.05 \mathrm{a}$ & $0.45 \pm 0.00 \mathrm{a}$ & $0.40 \pm 0.04 \mathrm{a}$ & $0.46 \pm 0.03 \mathrm{a}$ & $0.42 \pm 0.05 \mathrm{a}$ \\
Hypocotyl & $0.25 \pm 0.06 \mathrm{a}$ & $0.20 \pm 0.07 \mathrm{a}$ & $0.23 \pm 0.06 \mathrm{a}$ & $0.23 \pm 0.05 \mathrm{a}$ & $0.17 \pm 0.04 \mathrm{a}$ \\
Dry matter $(\mathrm{g})$ & & & & & \\
Root & $0.02 \pm 0.00 \mathrm{a}$ & $0.02 \pm 0.00 \mathrm{a}$ & $0.02 \pm 0.00 \mathrm{a}$ & $0.03 \pm 0.00 \mathrm{a}$ & $0.02 \pm 0.00 \mathrm{a}$ \\
Hypocotyl & $0.01 \pm 0.00 \mathrm{a}$ & $0.01 \pm 0.00 \mathrm{a}$ & $0.01 \pm 0.00 \mathrm{a}$ & $0.01 \pm 0.00 \mathrm{a}$ & $0.01 \pm 0.00 \mathrm{a}$ \\
\hline
\end{tabular}

$\mathrm{C}_{0}$ : soil never irrigated with the TWW; $\mathrm{C}_{3}{ }^{+}$and $\mathrm{C}_{10}{ }^{+}$: soils irrigated for 3 and 10 years, respectively; $\mathrm{C}_{3}{ }^{-}$ and $\mathrm{C}_{10}$ : soils not irrigated for 3 and 10 years, respectively. Values are means $\pm \mathrm{SD}$. Different letters indicate significant differences at $P<0.05$ according to Tukey's test

The leachates did not influence the plasma membrane integrity (Fig. 3), measured by Evans blue absorption.

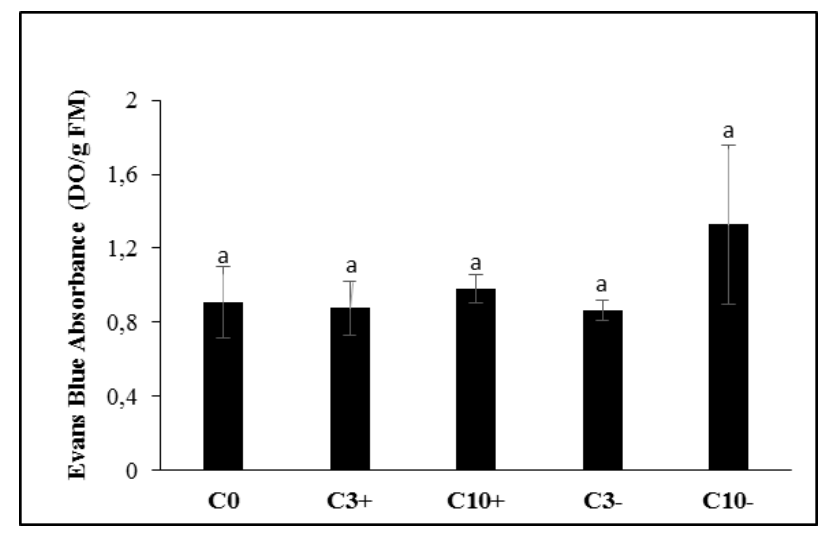

Figure 3. Plasma membrane integrity as determined by the Evans blue absorption of the V. faba root extracts while exposed to the soil leachate. $C_{0}$ : soil never irrigated with the $\mathrm{TWW} ; \mathrm{C}_{3}{ }^{+}$and $C_{10}{ }^{+}$: soils irrigated for 3 and 10 years, respectively; $C_{3}{ }^{-}$and $C_{10}{ }^{-}:$soils not irrigated for 3 and 10 years, respectively. Values are means $\pm S D$. Same letters indicate no significant differences at $P<0.05$ according to Tukey's test

\section{Genotoxicity assessment}

Figure 4 depicts the effect of the leachates on cell division and micronucleus induction. The response of the mitotic cycle to the leachates was different. $\mathrm{C}_{0}$ cells examined under microscope showed 37 divided cells per 1,000 counted cells. The frequencies of the mitotic phases increased significantly in $\mathrm{C}_{10}{ }^{+}$and $\mathrm{C}_{3}{ }^{-}$. The highest value was observed in $\mathrm{C}_{10}{ }^{+}$(53 divided cells per 1,000 counted cells). However, in 
soils receiving irrigation for 3 years $\left(\mathrm{C}_{3}{ }^{+}\right)$and those without TWW irrigation for 10 years $\left(\mathrm{C}_{10}{ }^{-}\right)$, the values dropped to less than 25 divided cells per 1,000 counted cells in $\mathrm{C}_{10^{-}}$.

Concerning micronucleus formation, only cells in interphase with one micronucleus were scored (Fig. 4). The control soil showed an induction of 30 micronuclei per 1,000 cells. The micronuclei formation in $\mathrm{C}_{3}{ }^{+}, \mathrm{C}_{10}{ }^{+}$and $\mathrm{C}_{3}{ }^{-}$was increased by a factor of 2 to 3 compared to $\mathrm{C}_{0} . \mathrm{C}_{10}{ }^{-}$was the only treatment with a micronuclei formation similar to $\mathrm{C}_{0}$.

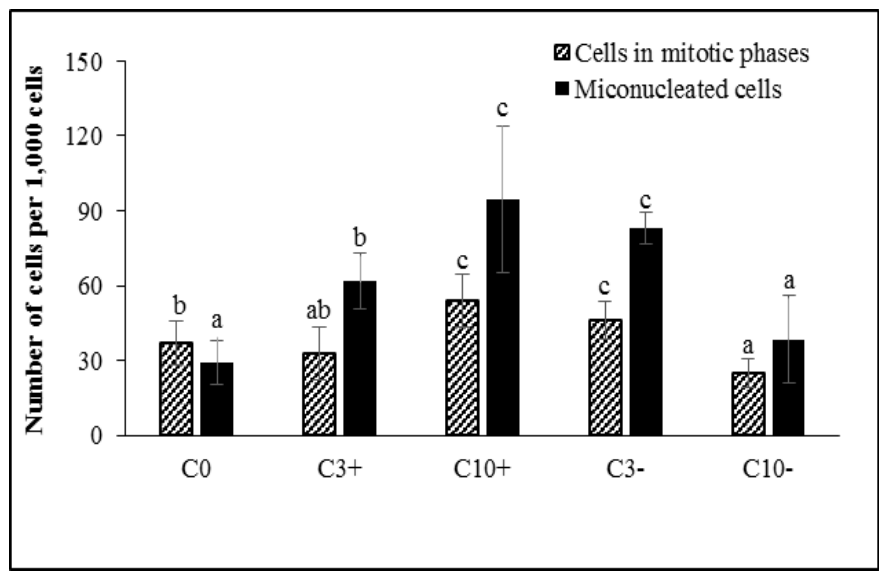

Figure 4. Number of cells in mitotic phases and micronucleated cells recorded between 1,000 cells in $V$. faba roots under exposure to the leachates. $C_{0}$ : soil never irrigated with the $T W W$; $C_{3}{ }^{+}$and $C_{10}{ }^{+}$: soils irrigated for 3 and 10 years, respectively; $C_{3}{ }^{-}$and $C_{10}{ }^{-}$: soils not irrigated for 3 and 10 years, respectively. Values are means $\pm S D$. Different letters indicate significant differences at $P<0.05$ according to Tukey's test

Simultaneously to the micronucleus formation, more or less similar types of aberrations were noticed as a response to the treatment with leachates (Fig. 5). The clastogenic aberrations include chromosome bridges, fragments and stickiness. Bridges were the most common structural aberration found in all treatments with values from 0.6 to 1.1 aberrations in 100 counted cells. Fragments were also noted in the anaphases and the telophases (Fig. 5) and stickiness, the less common clastogenic aberrations $(0.04-0.37 \%)$, were only observed in the prophases and the metaphases.

Aneugenic aberrations linked to the disfunction of the mitotic spindle included vagrant chromosomes, multipolar division and lagging chromosomes. In our study, we presented only lagging chromosomes aberrations, enclosing non-disjointed and isolated chromosomes (Fig. 5). The non-disjointed chromosomes frequency varied between 1 and $1.54 \%$, while isolated chromosomes ranged between 0.7 and $1.3 \%$.

The nuclear abnormalities like buds, lobulated nuclei, irregular shapes and pyknoses were also observed in cells exposed to the leachate (Fig. 6).

\section{Discussion}

In order to assess the effect of irrigation with secondary effluents on soils, 4 parcels with 4 different irrigation histories were chosen: 3 and 10 years of continuous irrigation $\left(\mathrm{C}_{3}{ }^{+}\right.$and $\mathrm{C}_{10}{ }^{+}$, respectively) and 3 and 10 years after TWW irrigation arrest $\left(\mathrm{C}_{3}{ }^{-}\right.$and $\mathrm{C}_{10}{ }^{-}$, respectively). In addition, a soil near the studied parcels never irrigated 
with TWW was used as control $\left(\mathrm{C}_{0}\right)$. All analyses were based on the leachate extracted from the surface layer of the soils. The leachate method allows the detection of the genotoxic and/or mutagenic chemicals which are not adsorbed by the solid particles (Cotelle et al., 2016).
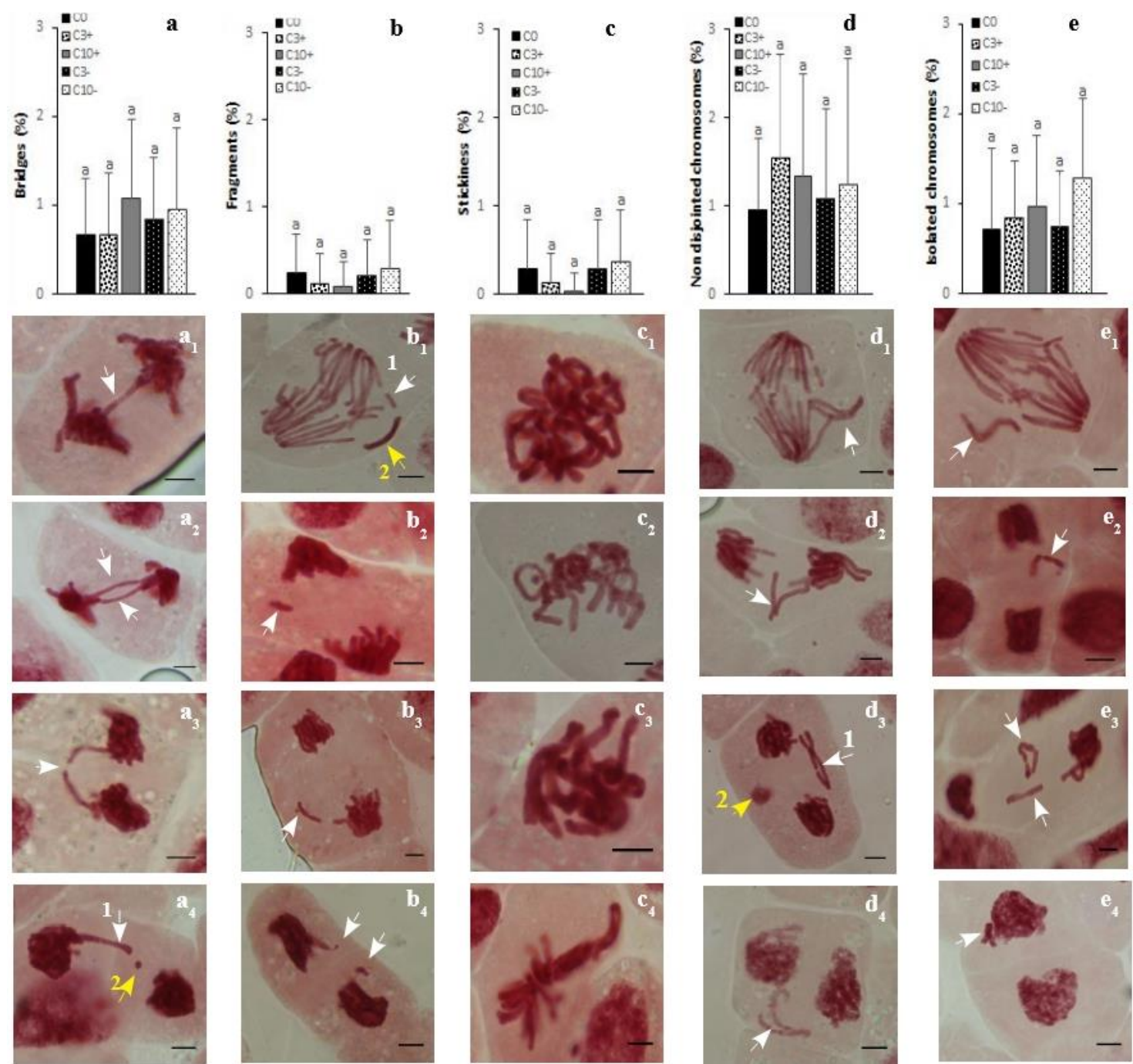

Figure 5. Abnormalities induced in the root-meristematic zone of the V. faba while exposed to the leachates of soils irrigated with the TWW in the Cebala-Borj Touil perimeter. Clastogenic abnormalities include bridges, fragments and stickinesses. (a) the percentage of bridges; $\left(a_{1}\right)$ the bridge in anaphase; $\left(a_{2}\right)$ two bridges in anaphase; $\left(a_{3}\right)$ the bridge break; $\left(a_{4}\right)$ the bridge break (1) with a chromosome fragment (2). (b) The percentage of fragments; $\left(b_{1}\right)$ the fragment (1) and the isolated chromosome (2) in the anaphase; $\left(b_{2}-b_{3}\right)$ - the fragment in telophase; $\left(b_{4}\right)$ two fragments in the telophase. (c) The percentage of stickiness; $\left(c_{1}\right)$ the stickiness in prophase;

$\left(c_{2}\right)$ the stickiness in the beginning of the telophase; $\left(c_{3}\right)$ the stickiness in the metaphase. The aneugenic abnormalities were represented by laggings. (d) The percentage of the non-disjointed chromosomes; $\left(d_{1}-d_{2}\right)$ the non-disjointed chromosomes in the anaphase, $\left(d_{3}\right)$ the non-disjointed chromosome (1) and the micronucleus (2) in the telophase; $\left(d_{4}\right)$ the non-disjointed chromosome. $(e)$ The percentage of the isolated chromosomes; $\left(e_{1}\right)$ the isolated chromosome in anaphase; $\left(e_{2}\right)$ the isolated chromosome in the telophase; $\left(e_{3}\right)$ two isolated chromosomes in the telophase; $\left(e_{4}\right)$ the isolated chromosome in the telophase ending. In $a, b, c, d$, and e, values are means $\pm S D$.

Different letters indicate significant differences at $P<0.05$ according to Tukey's test 

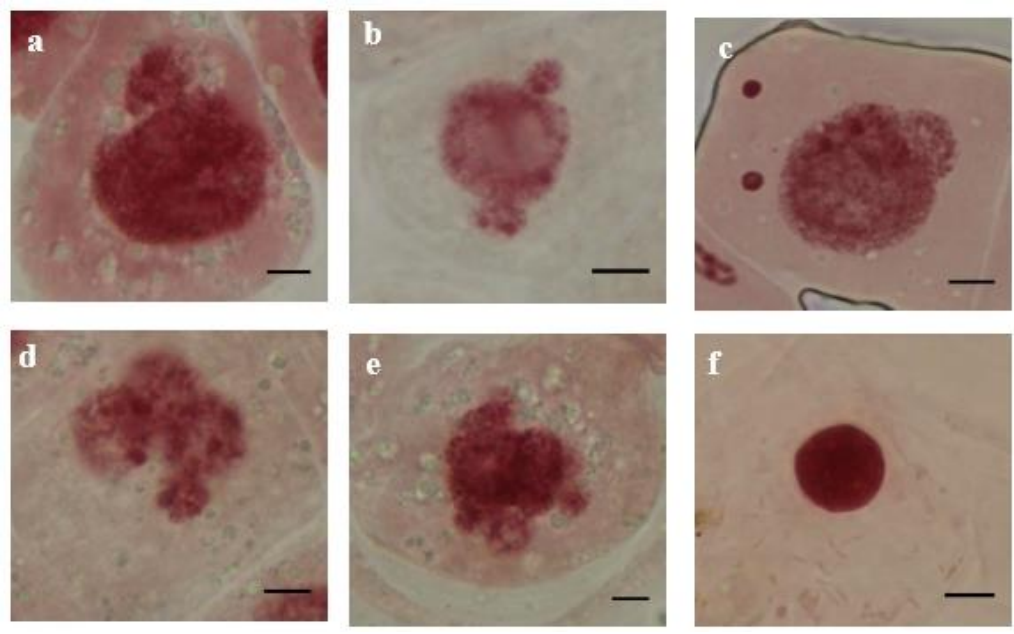

Figure 6. Nuclear abnormalities induced in the root-meristematic zone of $V$. faba under exposure to the leachates of soils irrigated with the TWW in the Cebala-Borj Touil perimeter. (a) The nucleus with a bud; (b) the nucleus with two buds; (c) the bimicronucleated cell with a budding nucleus; (d-e) the lobulated nuclei with irregular shape; $(f)$ the pyknosis (magnification: 1000x)

Most Tunisian studies showed an increase of salinity after irrigation with wastewater effluents (Klay et al., 2010; Belaid et al., 2012). The high salt content of Tunisian TWW is also an effect of the high initial salinity of the water used for irrigation. The water used for domestic purposes (drinking water) reached already $2.3 \mathrm{dS} / \mathrm{m}(1.5 \mathrm{~g} / \mathrm{l})$. The salinity of the secondary effluent is also influenced by side effects like the treatment plant location which may be near a salty lake and the sea or the infiltration of salty groundwater into the sewer network (Bahri, 2002). The long-term effects of irrigation with secondary effluents on calcisol fertility were analyzed by Belaid et al. (2012) for a soil near Sfax. They found that the 15-year irrigation period added a significant amount of ions and increased the soil salinity up to $4 \mathrm{dS} / \mathrm{m}$, even after the improvement of the TWW quality. Another investigation near Zaouit Sousse also revealed an increase of the soil salinity during the irrigation period (Klay et al., 2010). The depth profile showed an increase of salinity from top to the bottom $(120 \mathrm{~cm})$ with high levels in the deep horizons due to the downward salt transport caused by irrigation and winter rainfall.

In the irrigated perimeter Cebala-Borj Touil, the surface layer salinity is different. Despite the sampling after a rainy period with salt leached to the bottom of the soil, the $\mathrm{EC}_{1: 1}$ measurements exhibited different trends between soils with continuous irrigation and others where irrigation was stopped. Even irrigation with high salinity of TWW (5.26 - $5.36 \mathrm{dS} / \mathrm{m})$ decreased the $\mathrm{EC}_{1: 1}$ of the leachate from $2.03 \mathrm{dS} / \mathrm{m}$ after 3 years of TWW irrigation to $1.07 \mathrm{dS} / \mathrm{m}$ after 10 years. On the plots where TWW irrigation was stopped 10 years ago, salinity increased to $5 \mathrm{dS} / \mathrm{m}$. These salinity trends are probably related to the shallow and very saline groundwater with levels of 12 and $14 \mathrm{dS} / \mathrm{m}$ (2014 - 2015) (Dahmouni et al., 2019) and an average groundwater level of less than $150 \mathrm{~cm}$. During rainfall events, it can reach the surface because of insufficient drainage. Soil salinity may be significantly reduced after irrigation, because of leaching of salts to the lower horizons. In our case, the TWW reuse seems to decrease the soil salinity. This theory was supported by the second salinity tendency, which highlighted increases of the EC after TWW irrigation was stopped. 
In addition to salt, secondary effluents can contain significant amounts of toxic metals which can accumulate up to critical levels in the soil. The heavy metals of the leachates were compared to the $\mathrm{C}_{0}$ soil used as control. We found an increase of heavy metals in soils under long-term irrigation with TWW compared to the non-irrigated soil $\left(\mathrm{C}_{0}\right)$. Our results also confirm the findings of Khaskhoussy et al. (2015) about the effect of summer irrigation with TWW on Cebala soils. They found a significant increase of $\mathrm{Zn}, \mathrm{Co}, \mathrm{Cu}, \mathrm{Cd}, \mathrm{Pb}$ and $\mathrm{Ni}$ contents in $0-120 \mathrm{~cm}$ depth after the application of TWW. Klay et al. (2010) carried out another investigation of the development of the total load of heavy metals after long-term irrigation with the Sousse secondary effluent. The heavy metal contents of this effluent, used for irrigation during 14 years, were relatively low except for $\mathrm{Cd}$ and $\mathrm{Pb}$, which exceeded the Tunisian guideline values (TN106.03) and therefore accumulated preferentially in the deep horizons. The mobility of the heavy metals and their vertical distribution are closely related to the soil physicochemical parameters such as $\mathrm{pH}$ and salinity and to the quality of the irrigation water. In our study, the highest contents of $\mathrm{Cd}$ and $\mathrm{Fe}$ were found in the leachate of the soil with the longest TWW irrigation $\left(\mathrm{C}_{10}{ }^{+}\right)$, while the highest contents of $\mathrm{Cu}, \mathrm{Co}, \mathrm{Pb}, \mathrm{Ni}$ and $\mathrm{Cr}$ were found in the leachate of the soil where irrigation with TWW stopped 10 years ago $\left(\mathrm{C}_{10^{-}}\right)$, and where salinity was highest. It has been reported that increasing salinity reduces the organic complexation of the majority of metals as an effect of the increasing competition for available sites (Mantoura et al., 1978). This induces the solution from the solid phase and the leaching to the groundwater. The contamination of the Cebala groundwater and drainage water with heavy metals has been reported. Works, conducted by Dahmouni et al. (2018) and Dahmouni (2019), showed higher levels of Cd, Cr, Co and Pb levels compared to the TN106.02, Tunisian standard relative to the discharge of the wastewater effluents. This standard fixes the maximal levels of $\mathrm{Cd}, \mathrm{Co}, \mathrm{Ni}$ and $\mathrm{Pb}$ on $0.005 \mathrm{mg} / 1,0.01 \mathrm{mg} / \mathrm{l}, 0.2 \mathrm{mg} / \mathrm{l}$ and $0.1 \mathrm{mg} / \mathrm{l}$, respectively.

In this work, the analysis of the physicochemical proprieties of the leachates was completed by a genotoxic study with a $V$. faba root-micronucleus assay. This test is a widespread and reliable technique in ecotoxicology to assess the contamination of matrices like waters and soils (Zhang et al., 2004; Song et al., 2007; Cotelle et al., 2016; Souguir et al., 2019). The micronucleus test can be performed with $\mathrm{pH}$ values ranging between 3.5 and 9.0 for a more accurate evaluation of the chemical genotoxicity (Dyèvre et al., 2014). Up to now, no test of the TWW effect on the soil has been carried out with this method in Tunisia. Contamination risks were only evaluated based on physicochemical properties (Klay et al., 2010; Belaid et al., 2012). First, V. faba growth parameters and membrane integrity were measured. Root length, weight of fresh and dry matters of the plant organs and the Evans blue absorption did not show significant differences between the plants exposed to leachates and the control $\mathrm{C}_{0}$. However, the root tips showed genotoxic effects of the leachates, like changes of cell division, micronuclei, and abnormal chromosomes and nuclei.

The mitotic activity increased significantly in the roots exposed to $\mathrm{C}_{10}{ }^{+}$and $\mathrm{C}_{3}{ }^{-}$ compared to the control $\mathrm{C}_{0}$. Such effects were observed under a low concentration of the $\mathrm{NaCl}$ by Radic et al. (2005) who found that a salt concentration of $150 \mathrm{mM}$ markedly increased the mitotic activity in the cell-root tips of Centaurea ragusina. However, Teerarak et al. (2009) proved that all $\mathrm{NaCl}$ concentrations between 40 and $160 \mathrm{mM}$ inhibited cell division in the root tips of Allium cepa. A decline of the mitotic activity was also noticed especially in $\mathrm{C}_{10^{-}}$compared to $\mathrm{C}_{0}$, which may be attributed to 
the mitotic inhibition by contaminants in the leachate. They prevent or block the formation of various metabolites necessary for a normal sequence of mitosis. The reduction could also be caused by the blocking of the G2-phase in which tubulin is required for the formation of the mitotic spindle (Mahoney et al., 2006).

The $\mathrm{C}_{0}$ genotoxicity may result from the whole (antagonist/synergic) effects of contaminants present in this soil. The TWW irrigation seems to increase the micronucleus formation in soils with 3 and 10 years of TWW irrigation 2 to 3 times higher than the $\mathrm{C}_{0}$ soil. The highest level of micronucleus was observed after 10 years of irrigation in soil with low salinity and high concentrations of $\mathrm{Cd}$ and $\mathrm{Fe}$. The end of TWW irrigation 3 years ago still maintained genotoxic character of the soil through a high induction of micronucleus. However, the end of TWW irrigation 10 years ago did not influence the micronucleus formation and no significant difference was found between $\mathrm{C}_{0}$ and $\mathrm{C}_{10}$, apparently because of the low level of cells in mitotic division which also decreased the formation of micronuclei. The $\mathrm{C}_{10}{ }^{-}$leachate had the highest concentrations of $\mathrm{Cu}, \mathrm{Co}, \mathrm{Pb}, \mathrm{Ni}$ and $\mathrm{Cr}$. The sensitivity of the micronucleus assay to the heavy metals is well studied and many authors reported that the micronucleus frequency increased with increasing heavy metal concentrations and until it reaches a maximum beyond which fewer micronuclei were formed (Godet et al., 1996; Zhi-gang and Qiao-gu, 2009; Foltête et al., 2012). Wang (1999) found a positive correlation between the micronucleus frequency and $\mathrm{Cr}$ contents in $\mathrm{Cr}$-contaminated soils. Other positive correlations were found between the micronucleus induction and $\mathrm{Cu}, \mathrm{Cd}, \mathrm{Co}$ and $\mathrm{Fe}$ concentrations in paddy soils taken from an area where electronic waste was deposited (Jun-hui and Hang, 2009). $\mathrm{C}_{10}{ }^{-}$was also the leachate with the highest salinity $(5.03 \mathrm{dS} / \mathrm{m})$. The genotoxic character of salts has been previously studied by Teerarak et al. (2009) who showed the existence of micronucleus and chromosomal abnormalities under $\mathrm{NaCl}$ treatments. Recently, the higher incidence of micronuclei and the various types of chromosomal and nuclear aberrations were also investigated under either direct exposure to $\mathrm{NaCl}$ solution or indirectly through the leachate of a salty soil in the $V$. faba root tips (Souguir et al., 2017, 2018).

The slides prepared for the mitotic activity assessment and the micronucleus formation were used to detect the chromosomal and nuclear abnormalities in the root tips exposed to the leachates. The clastogenic aberrations included chromosome bridges, fragments and stickiness. The bridge was the most important structural chromosomal abnormality. It was found in all treatments and it is lethal for the cell (Hall and Garcia, 2006). It may be induced by some clastogenic substances in the leachates. Stickiness reflects a highly toxic and usually irreversible effect leading to cell death (El Ghamery et al., 2000). It is caused by DNA depolymerization, DNA condensation and the physical adhesion of the chromosomal proteins (Osterberg et al., 1984; Patil and Bhat, 1992). In our study, stickiness was the less abundant clastogenic aberration with values between 0.04 and $0.37 \%$.

In addition to the clastogenic abnormalities, the contaminants in the leachates seem to interrupt or cause a malfunction of the spindle function, an inappropriate chromosomal segregation when daughter cells are formed. In our study, the spindle alteration was detected through the appearance of lagging chromosomes in the anaphase and the telophase. Lagging chromosomes included non-disjointed and isolated chromosomes. The daughter cells enclosing a lagging chromosome may be formed with unequally sized or irregularly shaped nuclei during the interphase (El Ghamery et al., 2003). 
Nuclear abnormalities are characterized by morphological alterations in interphasic nuclei. These alterations were observed in $V$. faba under treatments and considered as nuclei carrying nuclear buds, lobulated nuclei with irregular shape and pyknosis. Cells with nuclear buds contain nuclear bodies connected to the main nucleus by a thin nucleoplasmic bridge (Bolognesi et al., 2013). Nuclear buds may emerge from the elimination of exceeding genetic material derived from polyploidization (Fernandes et al., 2007; Bolognesi et al., 2013). Irregular nuclei were also observed by Fernandes et al. (2007), who suggested that nuclear altered morphology occurred before the nuclear buds formation. Such nuclear alterations (irregularly shaped nuclei and nuclear buds) were attributed to $\mathrm{NaCl}$ (Souguir et al., 2018), $\mathrm{Pb}, \mathrm{Cr}$ and $\mathrm{Cu}$ ions (Liu et al., 1992, 1994; Abdel Migid et al., 2007). Pyknosis detected in cells exposed to the leachates was an irreversible condensation of chromatin in a nucleus of dying cells (Thomas et al., 2008).

The micronucleus test with soil leachates seems to be well suited to detect the genotoxicity, whereas growth parameters and the membrane integrity did not show any variation during the 2-day exposure period. A study of the sequential effects of $\mathrm{Cd}$ on genotoxicity and lipoperoxidation of $V$. faba roots during $48 \mathrm{~h}$ (Souguir et al., 2011) showed that the genotoxicity events occurred $12 \mathrm{~h}$ after $\mathrm{Cd}$ exposure and the prior plasma membrane integrity and the lipid peroxidation. The same metal was used in the study of Foltête et al. (2012) who found an early genotoxicity effect of a Cdspiked soil, while the first signs of toxicity appeared in the $V$. faba after a 2- month exposure period.

The genotoxicity detected in the Cebala leachates may be attributed to (i) the individual effects of contaminants, and/or (ii) the effects of synergic or antagonist interactions. Contaminants included salts, heavy metals and many other substances contained in TWW but not identified in our study. In addition to the effects of salts and heavy metals on cell division, micronucleus induction and chromosomal and nuclear abnormalities, salinity strongly enhances the uptake of heavy metals by plants due to the increasing mobility in the soil solution, even in an agricultural soil with very low concentrations of metals. The increased mobility of heavy metals depends on the total amount in the soil and the type of salt. It is attributed to the complexation of the saltderived anions with heavy metals and to the competition between salt-derived cations with heavy metal ions for sorption sites on the solid phase (Hatje et al., 2003; Acosta et al., 2011). Such an effect has been mainly studied with Cd. This element is one of the most dangerous metals due to its high mobility and to the low concentration at which it affects plants (Benavides et al., 2005; Rasheed et al., 2020).

The irrigation with TWW does not only add salts and heavy metals to soils, but also other contaminants from both domestic and industrial discharges. The transfer of the organic pollutants from the secondary effluents to the soils and their relative genotoxic effects has been broadly studied (Mahjoub et al., 2009; Haddaoui et al., 2016).

The genotoxicity observed in the root tips may also be due to the indirect effects of contaminants through the generation of free oxygen radicals or the alteration of the calmodulin synthesis or function (Ünyayar et al., 2006; Souguir et al., 2011). Calmodulin is specifically located in the mitotic spindle, it is involved in the movement of chromosomes and the control of polymerization and depolymerization of microtubules (Means and Dedman, 1980). 


\section{Conclusion}

This study investigates the effects of irrigation with TWW on cultivated soils using the micronucleus assay. The leachates from the first soil layer $(0-40 \mathrm{~cm}$ depth $)$ have different irrigation histories and exhibit different salinity levels, and various heavy metals. The genotoxicity was not accompanied by changes of growth parameters or membrane stability, which may confirm the role of the micronucleus test as a predictive biomarker of the harmful effects of long-term irrigation with the TWW on plants.

Two lessons can be learned from this work. The first concerns the agricultural use of TWW in semi-arid Mediterranean regions and the second relates to the use of genotoxicity biotest. Concerning the use of TWW, continue irrigation leads, even if standards are respected, to an increase in soil salinity and contamination by heavy metals which varies according to the metal. This evolution depends on the management of irrigation, whether continuous or intermittent. Despite the fact that, in our case, soil contamination would not be serious, more effort should be given to improve the quality of the secondary effluents at the outlet of the treatment plants and control soil and drainage system. For the use of the biotest, it proves very useful to evaluate in a thorough way, the risks on the crops before irrigation and during the irrigation cycles. It thus appears to be a powerful tool for the detection of anomalies that it would be recommended to integrate it into the control programs of the soils irrigated by TWW.

Acknowledgements. The authors are grateful to "The Ministry of High Education and Scientific Research" (MESRS, Tunisia) and to "The German Ministry of Research and Education" (BMBF, Germany) for supporting this work. Great acknowledgments to The National Research Institute of Rural Engineering, Water and Forestry for facilitating the implementation and the analysis of the experiments.

\section{REFERENCES}

[1] Abdel Migid, H. M., Azab, Y. A., Ibrahim, W. M. (2007): Use of plant genotoxicity bioassay for the evaluation of efficiency of algal biofilters in bioremediation of toxic industrial effluent. - Ecotoxicology and Environmental Safety 66: 57-64.

[2] Acosta, J. A., Jansen, B., Kalbitz, K., Faz, A., Martínez-Martínez, S. (2011): Salinity increases mobility of heavy metals in soils. - Chemosphere 85: 1318-1324.

[3] Bahri, A. (2002): Water Reuse in Tunisia: Stakes and Prospects. - In: Marlet, S., Ruelle, P. (eds.) Actes de l'atelier du PCSI. Workshop; May 28-29, 2002, Montpellier.

[4] Belaid, N., Neel, C., Kallel, M., Ayoub, T., Ayadi, A., Baudu, M. (2012): Long-term effects of treated wastewater irrigation on calcisol fertility: a case study of Sfax-Tunisia. - Agricultural Sciences 3: 702-713.

[5] Benavides, M. P., Callego, S. M., Tomaro, M. L. (2005): Cadmium toxicity in plants. Brazilian Journal of Plant Physiology 17: 21-34.

[6] Bolognesi, C., Knasmueller, S., Nersesyan, A., Thomas, P., Fenech, M. (2013): The HUMNxl scoring criteria for different cell types and nuclear anomalies in the buccal micronucleus cytome assay. An update and expanded photogallery. - Mutation Research 753: 100-113.

[7] Corrêa, A. X., Cotelle, S., Millet, M., Somensi, C. A., Wagner, T. M., Radetski, C. M. (2016): Genotoxicity assessment of particulate matter emitted from heavy-duty dieselpowered vehicles using the in vivo Vicia faba L. micronucleus test. - Ecotoxicology and Environmental Safety 127: 199-204.

[8] Cotelle, S., Dhyevre, A., Muller, S., Chenon, P., Manier, N., Pandard, P., Echairi, A., Silvestre, J., Guiresse, M., Pinelli, E., Giorgetti, L., Barbafieri, M., Silva, V. C., Engel, F., 
Radetski, C. M. (2015): Soil genotoxicity assessment-Results of an interlaboratory study on the Vicia micronucleus assay in the context of ISO standardization. - Environmental Science and Pollution Research 22: 988-995.

[9] Dahmouni, M. (2019): Effet à long terme et impact environnemental de l'irrigation avec les eaux usées traitées sur le sol, les eaux de drainage et la nappe : Cas du périmètre irrigué Cebala-Borj Touil, Tunis, Doctorat Thesis, Higher Agronomic Institute of ChottMeriem, University of Sousse, Tunisia.

[10] Dahmouni, M., Hörmann, G., Jouzdan, O., Hachicha, M. (2018): Export of salt and heavy metals in an area irrigated with treated wastewater: a case study from Cebala Borj-Touil (Tunisia). - Desalination and Water Treatment 102: 61-70.

[11] Dhyèvre, A., Foltête, A. S., Muller, S., Cotelle, S. (2014): Effects of soil pH on the Vicia micronucleus genotoxicity assay. - Mutation Research - Genetic Toxicology and Environmental Mutagenesis 774: 17-21.

[12] El Ghamery, A. A., El-Nahas, A. I., Mansour, M. M. (2000): The action of atrazine herbicide as an inhibitor of cell division on chromosomes and nucleic acids content in root meristems of Allium cepa and Vicia faba. - Cytologia 65: 277-287.

[13] El Ghamery, A. A., El-Kholy, M. A., El Yousser, M. A. (2003): Evaluation of cytological effects of $\mathrm{Zn}^{2+}$ in relation to germination and root growth of Nigella sativa L. and Triticum aestivum L. - Mutation Research 537: 29-41.

[14] El Hajjouji, H., Pinelli, E., Guiresse, M., Merlina, G., Revel, J. C., Hafidi, M. (2007): Assessment of the genotoxicity of olive mill wastewater (OMWW) with the Vicia faba micronucleus test. - Mutation Research - Genetic Toxicology and Environmental Mutagenesis 34: 25-31.

[15] Ferjani, N., Daghari, H., Hammami, M. (2013): Assessment of actual irrigation management in Kalâat El Andalous district (Tunisia): Impact on soil salinity and water table level. - Journal of Agricultural Sciences 5: 46-56.

[16] Fernandes, T. C., Mazzeo, D. E. C., Marin-Morales, M. A. (2007): Mechanism of micronuclei formation in polyploidizated cells of Allium cepa exposed to trifluralin herbicide. - Pesticide Biochemistry and Physiology 88: 252-259.

[17] Foltête, A. S., Masfaraud, J. F., Férard, J. F., Cotelle, S. (2012): Is there a relationship between early genotoxicity and life-history traits in Vicia faba exposed to cadmiumspiked soils? - Mutation Research - Genetic Toxicology and Environmental Mutagenesis 747: 159-163.

[18] Godet, F., Babut, M., Burnel, D., Veber, A. M., Vasseur, P. (1996): The genotoxicity of iron and chromium in electroplating effluents. - Mutation Research 370: 19-28.

[19] Grant, W. F. (1993): Plants as Detectors of Atmospheric Mutagens. - In: Corn, M. (ed.) Handbook of Hazardous Materials. Academic Press, San Diego.

[20] Hachicha, M. (2007): Saline soils and their reclamation in Tunisia. - Sécheresse 18: 4550 .

[21] Haddaoui, H., Mahjoub, O., Mahjoub, B., Boujelben, A., Di Bella, G. (2016): Occurrence and distribution of PAHs, PCBs, and chlorinated pesticides in Tunisian soil irrigated with treated wastewater. - Chemosphere 146: 195-205.

[22] Hall, E. J., Garcia, A. J. (2006): Radiobiology for the Radiologist. - Lippincott Williams and Wilkins, Philadelphia.

[23] Hatje, V., Payne, T. E., Hill, D. M., Mcorist, G., Birch, G. F., Szymczak, R. (2003): Kinetics of trace element uptake and release by particles in estuarine waters: effects of pH, salinity, and particle loading. - Environment International 29: 619-629.

[24] INNORPI (1989): Environment Protection. Use of Reclaimed Water for Agricultural Purposes. Physical, Chemical and Biological Specifications. - Tunisian Standards, NT 106.03.

[25] ISO 10693 (1995): Soil quality, Determination of Carbonate Content. Volumetric Method. - ISO, Geneva. 
[26] JORT (2018): Order of the Minister of the Local Affairs and Environment and the Minister of Industry and Small and Medium Enterprises of the 26 March 2018. Setting the Limit Values for Effluent Discharges into the Receiving Environment. - Tunisian Standards, NT 106.02.

[27] Jun-hui, Z., Hang, M. (2009): Eco-toxicity and metal contamination of paddy soil in an ewastes recycling area. - Journal of Hazardous Materials 165: 744-750.

[28] Kallel, M., Belaid, N., Ayoub, T., Aayadi, T., Ksibi, M. (2012): Effects of treated wastewater irrigation on soil salinity and sodicity at El Hajeb region (Sfax-Tunisia). Journal of Arid Land 22: 65-68.

[29] Khaskhoussy, K., Kahlaoui, B., Messoudi, B. N., Juzdan, O., Dakheel, A., Hachicha, M. (2015): Effect of treated wastewater irrigation on heavy metals distribution in a Tunisian soil. - Engineering, Technology and Applied Science Research 5: 805-810.

[30] Klay, S., Charef, A., Ayed, L., Houman, B., Rezgui., F. (2010): Effect of irrigation with treated wastewater on geochemical properties (saltiness, C, N and heavy metals) of isohumic soils (Zaouit Sousse perimeter, Oriental Tunisia). - Desalination 253: 180-187.

[31] Liu, D., Jiang, W., Li, M. (1992): Effects of trivalent and hexavalent chromium on root growth and cell division of Allium cepa. - Hereditas 117: 23-29.

[32] Liu, D., Jiang, W., Wang, W., Zhao, F., Lu, C. (1994): Effects of lead on root growth, cell division, and nucleolus of Allium cepa. - Environmental Pollution 86: 1-4.

[33] Mahjoub, O., Leclercq, M., Bachelot, M., Casellas, C., Escande, O., Balaguerc, P., Bahri, A., Gomez, E., Fenet, H. (2009): Estrogen, aryl hysdrocarbon and pregnane X receptors activities in reclaimed water and irrigated soils in area (Nabeul, Tunisia). - Desalination 248: 104-113.

[34] Mahoney, N. M., Gohta, G., Douglass, A. D., Vale Making, R. D. (2006): Making microtubules and mitotic spindles in cells without functional centrosomes. - Current Biology 16: 564-569.

[35] Mantoura, R. F. C., Dickson, A., Riley, J. P. (1978): The complexation of metals with humic materials in natural waters. - Estuarine and Coastal Marine Science 6: 387-408.

[36] Means, A. R., Dedman, J. R. (1980): Calmodulin in endocrine cells and its multiple roles in hormone action. - Molecular and Cellular Endocrinology 19: 215-227.

[37] Osterberg, R., Persson, D. Jursell, G. (1984): The condensation of DNA by chromium (III) ions. - Journal of Biomolecular Structure and Dynamics 2: 285-290.

[38] Patil, B. C., Bhat, T. G. I. (1992): A comparative study of MH and EMS in the induction of chromosomal aberrations on lateral root meristem in Clitoria termata L. - Cytologia 57: 259-264.

[39] Radic, S., Prolic, M., Pavlica, M., Pevalek-Kozlina, B. (2005): Cytogenetic effects of osmotic stress on the root meristem cells of Centaurea ragusina L. - Environmental and Experimental Botany 54: 213-218.

[40] Rasheed, A., Fahad, S., Aamer, M., Hassan, M. U., Tahir, M. M., Wu, Z. M. (2020): Role of genetic factors in regulating cadmium uptake, transport and accumulation mechanisms and quantitative trait LOCI mapping in rice. A review. - Applied Ecology and Environmental Research 18(3): 4005-4023.

[41] Renjana, P. K., Anjana, S., Thoppil, J. E. (2013): Evaluation of genotoxic effects of baking powder and monosodium glutamate using Allium cepa assay. - International Journal of Pharmacy and Pharmaceutical Sciences 5: 311-315.

[42] Smaka-Kincl, V., Stegnar, P., Lovka, M., Toman, J. M. (1996): The evaluation of waste, surface and ground water quality using the Allium test procedure. - Mutation Research Genetic Toxicology 368: 171-179.

[43] Song, Y. F., Gong, P., Wilke, B. M., Zhang, W., Song, X. Y., Sun, T. H., Ackland, M. L. (2007): Genotoxicity assessment of soils from wastewater irrigation areas and bioremediation sites using the Vicia faba root tip micronucleus assay. - Journal of Environmental Monitoring 9: 182-186. 
[44] Souguir, D., Abd-Alla, H. I., Hörmann, G., Hachicha, M. (2018): Chromosomal and nuclear alterations in the root-tip cells of Vicia faba induced by sodium chloride. - Water Environment Research 90: 164-171.

[45] Souguir, D., Ferjani, E., Goupil, P., Ledoigt, G. (2008): Exposure of Vicia faba and Pisum sativum to copper-induced genotoxicity. - Protoplasma 233: 203-207.

[46] Souguir, D., Ferjani, E., Goupil, P., Ledoigt, G. (2011): Sequential effects of cadmium on genotoxicity and lipoperoxidation in Vicia faba roots. - Ecotoxicology 20: 329-336.

[47] Souguir, D., Hörmann, G., Hachicha, M. (2017): Evaluation de la génotoxicité d'un sol salin irrigué par des eaux usées traitées: cas du sol de Kalaât Landelous (Tunisie). - Étude et Gestion des Sols 24: 27-135 (in French).

[48] Souguir, D., Hörmann, G., Hachicha, M. (2019): Genotoxicity assessment of the groundwater quality in the Téboulba region-Tunisia using the Vicia faba micronucleus test. - Applied Ecology and Environmental Research 17(2): 3959-3971.

[49] Sta, C., Ledoigt, G., Ferjani, E., Goupil, P. (2012): Exposure of Vicia faba to sulcotrione pesticide induced genotoxicity. - Pesticide Biochemistry and Physiology 103: 9-14.

[50] Teerarak, M., Bhinija, K., Thitavasanta, S., Laosinwattana, C. (2009): The impact of sodium chloride on root growth, cell division, and interphase silver-stained nucleolar organizer regions (AgNORs) in root tip cells of Allium cepa L. - Scientia Horticulturae 121: 228-232.

[51] Thomas, P., Harvey, S., Gruner, T., Fenech, M. (2008): The buccal cytome and micronucleus frequency is substantially altered in Down's syndrome and normal ageing compared to young healthy controls. - Mutation Research 638: 37-47.

[52] Ünyayar, S., Celik, A., Cekic, F. O., Gozel, A. (2006): Cadmium-induced genotoxicity, cytotoxicity and lipid peroxidation in Allium sativum and Vicia faba. - Mutagenesis 21: 77-81.

[53] Wang, H. Q. (1999): Clastogenicity of chromium contaminated soil samples evaluated by Vicia root-micronucleus assay. - Mutation Research - Fundamental and Molecular Mechanisms of Mutagenesis 426: 147-149.

[54] Yi, M., Yi, H., Li, H., Wu, L. (2010): Aluminum induces chromosome aberrations, micronuclei, and cell cycle dysfunction in root cells of Vicia faba. - Environmental Toxicology 25: 124-129.

[55] Zhang, H., Cheng, X., Ba, Y. (2004): Mutagenicity of water from Yangling-Xingping section of Weihe river and wastewater from paper mills along the river. - Journal of Environmental Health 21: 96-98.

[56] Zhi-gang, Y., Qiao-gu, F. (2009): Utilization of micronucleus test technique in Vicia faba root tips to evaluate the genetic toxicity of three heavy metal ions. - Fujian Agriculture and Forestry University 38: 396-399. 